\title{
Qualitative methods in HRM research: they can offer more than an escape route from statistics...
}

\author{
Kvalitatív módszerek az emberierőforrás-kutatásokban: \\ nem csak arra jók, hogy „megússzuk a statisztikát”...
}

Handbook of Qualitative Research Methods on HRM: Innovative Techniques Edited by Keith Townsend, Rebecca Loudoun, David Lewin. Edward Elgar Pub. 288 p.

\author{
KUN ANDRÁS ISTVÁN ${ }^{1}$
}

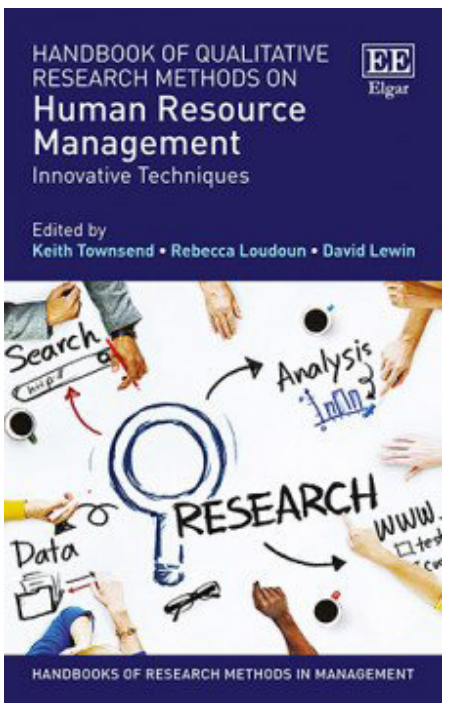

Qualitative research methods became more and more popular in business and management disciplines. Even in economics there is an intense dispute about the wasted opportunities due to the general refusal of qualitative approaches (Lenger 2019). We should also mention, however, that successful qualitative research projects always existed in various areas of economics, they were just not frequent and not part of the mainstream routine.

At the same time, in business and management studies, quantitative methods were never as dominant as in economics. One of the main reasons behind this is that managerial investigations are always have a lower level of abstraction, are more focused on the complexity of real problems. On the contrary, for many management disciplines to become a 'quantified, formalised science' is hardly an achievable dream. Management Science (or Scientific Management) - descending from Taylorism - refers to those few management problem areas that have succeeded in turning into formalised disciplines (see Anderson - Sweeney - Williams - Camm - Cochran 2015). Qualitative data analysis is most productive in areas abound in subjective, non-formalisable data and processes. Organisational studies, marketing and human resource management (hereinafter HRM) are among such areas.

The Handbook of Qualitative Research Methods on Human Resource Management: Innovative Techniques (Townsend, Loudoun, and Lewin 2016) was first published

\footnotetext{
${ }^{1}$ University of Debrecen, Department of Human Resource Management.
} 


\section{TEMATIKUS TANULMÁNYOK - Recenzió}

by the Edward Elgar as the fourth part of the book series Handbooks of Research Methods in Management, designed to provide a starting tool-set for new $\mathrm{PhD}$ students in various business, management or related social sciences ${ }^{2}$. The editor of the series is Mark N. K. Saunders (University of Birmingham, UK), whose name could be familiar to HRM and business researchers and students: he is co-author of several textbooks (e.g. Saunders - Lewis - Thornhill 2016; Townsend and Saunders 2018) and papers (among others: Saunders - Bezzina 2015; Saunders 2012) about research methodology for management and business.

The volume under review introduces rare and/or underutilized qualitative research methods. The editors and authors claim that the dominance of quantitative methods in management science is unreasonable, and could be mitigated through the innovation of qualitative research. Such innovation became much more possible now, than it was decades ago. Two main sources of the expected renewal are technology (hardware, software, infrastructure) and the research experience accumulated through the many years.

Based on their professional and research background the assigned trio of editors was an appropriate choice for a book with the aims above. Keith Townsend (Griffith University, Australia) is a productive author with more than a half hundred referred journal articles, five monographies, more than fifteen book chapters, up to the reviewed books publishing date. His research area mostly includes HRM, leadership and employment relations topics. Besides his academic career he is active in the practitioner community as well. Rebecca Loudoun is also a researcher of HRM and employment relations at the same university, however in her case there is a strong focus on workplace health. She possesses considerable experience as both an academic researcher and a consultant. Her list of publications consisted more than 30 records until 2016. The third editor, David Lewin (UCLA, USA), had the longest research history from the tree with more than a hundred publications of various types (book, professional and scientific articles). His main research interests are employment relations and HRM. Ha was and is holder of several leading and administrative positional is academic and professional organizations). Thus, the three editors could evaluate the innovativeness and usefulness of the HRM research methods from both a scientific and a practical viewpoint.

The book consists of eighteen individual studies (chapters) on 261 pages: one introductory study by the editors (Qualitative research in HRM: innovation over

\footnotetext{
${ }^{2}$ The previous three books in the series were the Handbook of Research Methods on Intuition (Sinclair 2014), the Handbook of Research Methods on Human Resource Development (Saunders - Tosey 2015), Handbook of Research Methods on Trust (Lyon - Möllering - Saunders 2015). After the currently reviewed volume three other areas of management have received their handbooks: Handbook of Methods in Leadership Research (Schyns - Hall - Neves 2017), Handbook of Research Methods for Tourism and Hospitality Management (Nunkoo 2018), Handbook of Research Methods on the Quality of Working Lives (Wheatley, 2019).
} 
stagnation) and seventeen more in four main parts. The chapters are unevenly distributed among the four parts: three belongs to Part I, five to Part II, six to Part III and three to Part IV. The eighteen studies are written by twenty-six authors including the editors. Since they have affiliations at institutions in the UK (14 authors), in Australia (10), in the USA (1) and in Germany (1), the Anglo-Saxon approach to HRM dominates the book. The volume is well equipped with tables (18), boxes (5), figures (18), and examples (uncounted) to help the reader understand the introduced methods and to learn how to use them in practice.

Although the individual studies are not building on or connected to each other the four major units are following the ideal, linear research process. Part I is about planning a fully or partially qualitative research project. When the broad-brush design is worked out, a researcher needs to find an (or more) appropriate and available data source(s). Part II offers some choices of data sources that are not fully utilized in the mainstream HRM research, yet. The next step is gathering data from an available source, thus Part III introduces some innovative methods to help the reader in this phase of the research process. Many researchers could agree that data analysis is the most critical step in qualitative research projects, because qualitative data are far less standardisable and the subjective elements are impossible to be kept out. Part IV shows some solutions for researchers facing this challenge or similar kind of challenges.

The first part (Part I) provides the readers insight into Designing qualitative projects in three chapters. The first chapter, authored by Roslyn Cameron (Curtin University, Australia), explores the role of qualitative methods in mixed methods designs. The author suggests that in mixed method designs (when both quantitative and qualitative methods are utilized) the qualitative part can balance out the weaknesses of the quantitative methods, and is able to provide meaning to the research, connecting it to the context. The second, Anchoring qualitative methods for longitudinal studies, is written by Rebecca Loudoun and Keith Townsend. It investigates how one can design a qualitative research with longitudinal time horizon. The third chapter by Sally Sambrook (Bangor University, UK), Autoethnography: a novel way to study HRM, offers a technique for using subjective, personal aspects of HRM practise in research projects.

Part II focuses on Innovations in data sources, offering new, previously nonresearchable areas to study. In the fourth chapter, Richard Johnstone (Queenslan University of Technology, Australia) shows the possibilities of Using legal research methods in human resource management research. A usual HR researcher is not a trained legal expert, although HRM is strongly bound and affected by external and internal rules and regulations. Consequently, this study could be useful for a wide range of readers. The use of news media as a data source in HRM research: exploring society's perceptions is a paper by three female researchers from the Griffith University, Australia: Sheryl Ramsey, Sara Branch and Jacqueline Ewart. This and the 


\section{TEMATIKUS TANULMÁNYOK - Recenzió}

following study - Netnographical methods and the challenge of researching hidden and secretive employee social media practices (by James Richards, Heriot-Watt University, UK) - are both dealing with today's leading and continuously evolving data sources of the electronic media. The available electronic data are enormous in volume and are covering more and more aspects of HRM, thus it could come handy to know how to use them. In contrast to the fifth and sixth studies, the last two chapters in Part II are analysing the potentials of two of the possibly oldest sources of scientific knowledge and their usability in HRM research: Doing historical research in human resource management: with some reflections on an academic career (by Peter Ackers, De Montfort University, Leicester, UK) and Thinking about philosophical methods in human resources (by Kerrie L. Unsworth, Leeds University, UK, and Matthew T. Hardin, independent researcher, UK). Both historical and philosophical ways of research had centuries to prove themselves worthy and to get sophisticated; the authors reveal some ways how HRM research could successfully utilize these methods.

After the innovative inputs for HRM research the third major part of the book investigates Innovations in data collection methods. With six chapters this is the longest part in the volume. The first study in this part (Chapter 10), An experiment with "the miracle question": an innovative data collection technique in HR research, by one of the editors, Keith Townsend, publishes interesting results of the experimental adaptation of "solution-based" questioning technique from psychology to HRM. The core idea behind this kind of questioning is to ask the respondent what should be different in a hypothetical, ideal setting (If a 'miracle' would happen and turn the situation ideal, what would be different?) of their work-life, job, etc., instead of asking about the problems in the present.

Using photo-elicitation to understand experiences of work-life balance by Catherine Cassel (Leeds University, UK), Fatima Malik (University of Bradford, UK) and Laura S. Radcliffe (University of Liverpool, UK) is the eleventh chapter. In the age of digital photographing, mobile phones, and social media there are a practically infinite and continuously growing amount of photos available (publicly or not) for the researchers about every part of life. Even if HRM is not a 'photography-intensive' management function, still there are subareas rich in moments captured in pictures. Work-life balance is just one of them. Among others, team-building and ceremonial events could also be an analysable area.

Using qualitative repertory grid interviews to gather shared perspectives in a sequential mixed methods research designis the twelfth study, written by Céline Rojon (University of Edinburgh, UK), Mark Saunders and Almuth McDowall (University of London, UK). Repertory Grid Techniques (RGTs) are widely used in many disciplines. It is a familiar part of HRM as well - most readers might know it as a job analysis technique -, but is rarely considered as an initial, conceptualizing (qualitative) method in mixed method research designs. This study helps to learn the technique and illustrates its usefulness. 


\section{TEMATIKUS TANULMÁNYOK - Recenzió}

In the thirteenth chapter - Free verbal associations: measuring what think about employee participation - Werner Nienhüser (University of Duisburg-Essen, Germany) presents a sample research (a telephone survey about attitudes toward employee participation) about how spontaneous associations could be useful for HR researchers.

A technique designed to capture daily activities or practices as they actually happen through a given time interval is adapted to HRM in the next chapter by Laura S. Radcliffe: Using qualitative diaries to uncover the complexities of daily experiences. According to the author's findings, the greatest advantage of this method in HRM is to help understanding the dynamics of complex issues and experiences.

Autoethnographic vignettes in HRM by Mark Learmonth and Michael Humphreys from Durham University, UK is the last chapter in this Part. Although this technique has many pitfalls (limitations of personal memory, self-representation biases, the lack of critical distance), the authors could still support some serious advantages of utilizing stories including self-reflections and subjective personal experiences. Autoethnographic vignettes can hardly replace more conventional methods, but could provide very useful support - in the form of samples and illustrations - for understanding and exploration.

The closing triad of studies (Part IV) presents three methods for Innovative data analysis. Qualitative data analysis can be much more time consuming compared to quantitative procedures. Fortunately, many softwares are available on the market that can provide significant help. Computer-supported qualitative research, the sixteenth chapter - written by two researchers of University of New South Wales, Australia, Julie Cogin and Ju Li Ng - provides a useful introduction on how to use computers in qualitative data processing.

Cognitive mapping is a technique to structure and clarify thoughts and ideas for our own understanding or for better communication with others. Gail Clarkson (University of Leeds, UK) shows the use of this method in HRM through an example in the seventeenth chapter: Cross-cultural HRM research: a potential of causal cognitive mapping.

Deriving behavioural role descriptions from the perspectives of job-holders: an illustrative example by Richard Winter (Australian National University, Australia) presents a combination of two other mapping techniques in use: interview code mapping and role/job mapping.

In sum, this handbook is a valuable tool for any researcher - not only for PhD students - who would like to get same basic knowledge about new ideas or about how to introduce qualitative methods into his or her research. The methods and techniques in the book are not new, according to their statement, this was not an aim of the editors. These methods are innovative because they are unusual on the field of HRM research (even if they are frequent in other areas), or because they can be used in a non-regular way. Maybe this is the greatest advantage of this handbook for the 


\section{TEMATIKUS TANULMÁNYOK - Recenzió}

readers: they can widen their tool-set for research with methods novel for them, and at the same time they can be sure about the reliability of these tools.

\section{References}

Anderson, D. R. - Sweeney, D. J. - Williams, T. A. - Camm, J. D. - Cochran, J. J. (2015): An Introduction to Management Science: Quantitative Approaches to Decision Making. Cengage Learning, Mason.

Lenger, A. (2019): The Rejection of Qualitative Research Methods in Economics. Journal of Economic Issues Vol. 53. (4) pp. 946-965. DOI: 10.1080/00213624. 2019.1657748

Lyon, F. - Möllering, G. - Saunders, M. N. K. (2015): Handbook of Research Methods on Trust. Edward Elgar, Cheltenham.

Nunkoo, R. (ed.) (2018): Handbook of Research Methods for Tourism and Hospitality Management. Edward Elgar, Cheltenham.

Saunders, M. N. K. (2012): Web versus Mail: The Influence of Survey Distribution Mode on Employees' Response. Field Methods. 24(1): 56-73. DOI: 10.1177/ $1525822 X 11419104$

Saunders M. N. K. - Bezzina, F. (2015): Reflections on conceptions of research methodology amongst management academics. European Journal of Management. 33(5): 297-304. DOI: 10.1016/j.emj.2015.06.002

Saunders, M. N. K. - Lewis, P. - Thornhill, A. (eds.) (2016): Research Methods for Business Students $\left(7^{\text {th }}\right.$ edn). Pearson Education, Harlow.

Saunders, M. N. K. - Tosey, P. (eds.) (2015): Handbook of Research Methods on Human Resource Development. Edward Elgar, Cheltenham.

Schyns, B. - Hall, R. J. - Neves, P. (eds.) (2017): Handbook of Methods in Leadership Research. Edward Elgar, Cheltenham.

Sinclair, M. (ed.) (2014): Handbook of Research Methods on Intuition. Edward Elgar, Cheltenham.

Townsend, K. - Loudoun, R. - Lewin, D. (eds.) (2016): Handbook of Qualitative Research Methods on Human Resource Management: Innovative Techniques. Edward Elgar, Cheltenham.

Townsend, K. - Saunders, M. N. K. (2018): How to keep your research project on track: Insights from when things go wrong. Edward Elgar, Cheltenham.

Wheatley, D. (ed.) (2019): Handbook of Research Methods on the Quality of Working Lives. Edward Elgar, Cheltenham. 